\title{
Assessment of Service Quality on Customer Satisfaction in Selected Hotels in Abeokuta Metropolis, Ogun State, Nigeria
}

\author{
${ }^{1 *}$ OGUNGBAYI, GB; ${ }^{2}$ OLATIDOYE, OP; ${ }^{3}$ AGBEBI, PA \\ ${ }^{I}$ Department of Home Science and Hospitality Management, Olabisi Onabanjo University, Ayetoro Campus, Ogun State. Nigeria. \\ ${ }^{2}$ Department of Food Technology, Yaba College of Technology, P.M.B 2011, Yaba, Lagos State, Nigeria. \\ ${ }^{3}$ Department of Hospitality Management, Moshood Abiola Polytechnics, Abeokuta, Ogun State \\ ${ }^{*}$ Corresponding Authors Address: gafar.ogungbayi@oouagoiwoye.edu.ng
}

\begin{abstract}
This study was carried out to assess service quality on customer satisfaction in some selected hotels in Abeokuta Metropolis. A total of one hundred and fifteen (115) structured questionnaires was distributed, out which ninety seven (97) respondents representing $84.3 \%$ completed and returned the questionnaire. The results showed that the socioeconomic characteristics of respondents involved in hotel patronage were $81.4 \%$ (male) and $18.6 \%$ (female) with $58.7 \%$ of the total respondents rated unsatisfactory with mean value of ' 2.68 ', $52 \%$ of respondents rated service experienced unsatisfactory with mean value of ' 2.62 ', $71.1 \%$ of respondents consented to the various solutions offered . The chi-square showed there was significant relationship $\left(x^{2}=789.537^{a}>x^{2}=9.488, p<0.05\right)$ between socio-economic characteristics of respondents and the level of their satisfaction with service qualities in the hotels. Also, there was significant relationship $\left(x^{2}=837.990^{a}>x^{2}=9.488, p<0.05\right)$ between the various service qualities and customer satisfaction. It was further confirmed that service quality delivery to customers was the major challenge of all the hotels in Abeokuta metropolis which is on how to deliver the service to customers in a way that will bring satisfaction to them. This study therefore recommended that hotels owners should constantly embark on staff training in 'service quality delivery' that will bring about customer satisfaction at all times.
\end{abstract}

DOI: https://dx.doi.org/10.4314/jasem.v23i6.6

Copyright: Copyright $(02019$ Ogungbayi et al. This is an open access article distributed under the Creative Commons Attribution License (CCL), which permits unrestricted use, distribution, and reproduction in any medium, provided the original work is properly cited.

Dates: Received: 13 May 2019; Revised: 19 June 2019; Accepted 07 June 2019

Keywords: Hotel industry, service quality, customer satisfaction

Customer satisfaction is a critical success factor in service organizations. Hotel industries in developing countries also have to compete with others and have to satisfy local and international customers, because, today ${ }^{\text {ee }}$ customers are more aware, educated and open to a lot of information through web sources, internet, bulletins, magazines, journals, articles, etc., (Armstrong, Mok et al. 1997; Padma and Rajendran 2010). Customer satisfaction is a key to building lasting relationships with consumers. Satisfied customers repurchase the service, recommend and encourage others to use the service, develop positive word of mouth toward the service and the organization, pay less attention to competitive brands and advertising, are less sensitive to price and buy other services (Zekiri, 2011). A dissatisfied consumer, on the other hand, responds differently. As a satisfied customer tells people about a good service experience, dissatisfied customer complains to even more people than a satisfied customer does. In the hotel industry, service quality received much attention from both researchers and practitioners because of its positive impact on financial performance, customer satisfaction, and retention (Akbaba, 2006; Ghobadian, et al, 1994; Gržini'c, 2007; MartinezCaro \& Roemer,
2006; Tam, 2000). Ultimately, quality enhancement is a key determinant for the success of an organization in today's competitive market environment (Anderson et $a l, 1994)$. Therefore, marketers' in the service industry should pay close attention to the issue of service quality (Zeithaml et al, 1996). By studying the overall interest and the decision making process of buyers, service delivering organizations might help consumers to go through it. Hence, this study will focus on hotels so as to identify basic service quality attributes, service delivery and customer satisfaction among hotels.

\section{MATERIALS AND METHODS}

The Study Area: Abeokuta City was chosen as the study location, the state capital of Ogun State in Southwest Nigeria.

Source of Data: In order to get appropriate data, the study employed both primary and secondary sources of data. Primary data were collected through questionnaires from sample respondents of Hotels. Secondary sources of data were collected from relevant books, journals, publications and other online information. 
Population of the Study: The population of the study is basically the customers who patronize the hotels in Abeokuta metropolis. There are One hundred and twenty Five (125) different hotels in Abeokuta metropolis.

Sampling procedure and Sample size: A systematic sampling technique known as multi-stage sampling was used as follows:

Stage 1: This involved the stratification of Abeokuta into ten (10) zones with each zone having their number of hotels.

Stage 2: Thirty percent (30\%) of the hotel population in each of the ten (10) zones was selected for representative sample.

Stage 3: The population of resident guests which was used as respondents in this study was affected in data through personal contacts with the management of the hotel which gave permission to obtain necessary information from guests' lodging records. Thus, the total average number of resident guests in the selected hotels was 569 per week while $20 \%$ (115) of this population was selected as sample size of respondents for the study as shown in the table below. The determination of population of resident guests was done through personal contacts with the management who gave permission to obtain necessary information from guests' lodging records.

Data Analysis: The method of analysis was mainly descriptive analysis. The data obtained by the close ended questionnaires on participants demographic and overall service quality, customer satisfaction and loyalty detail were analyzed quantitatively using percentage, frequency, and mean. To do this, SPSS version 16 programs were employed to analyze the data.

\section{RESULTS AND DISCUSSION}

Socio-economic characteristics of respondents: Table 1 below shows that majority of our respondents were male as they accounted for $81.4 \%$ of the selected population with female accounting for $18.6 \%$. The implication of this is that the hotels in Abeokuta enjoy impressive patronage of male than female as indicated in Table 1. Majority of the respondents falls between the ages of 30-40 years as they accounted for about $47.4 \%$, while $29.9 \%$ of ages $40-50$ years also patronize the hotels. This implied that hotels in Abeokuta enjoy the influx patronage of customers between the ages of 30-50years. Marital status is expected to influence respondents' level of their exposure to hospitality industry, financial buoyancy and satisfaction with the service qualities of the hotel which could have positive or negative influence on the performance of the hotel. Also, majority of the respondents are married as they accounted for $79.4 \%$ of the respondents in the study. This indicates that hotels in Abeokuta Metropolis have high records of patronage of married people (Table 1). It was pertinent to know that education was a vital point of note in enlightenment and tendency towards innovative in quality service. There was undoubted strong relationship between education and dimensions of service qualities in hotels.

Table 1 below also indicated that $11.3 \%$ of the respondents had postgraduate qualification, $75.3 \%$ had first degree and higher diploma, $10.3 \%$ had diploma certificate while $03.1 \%$ had SSSCE/GCE/ qualifications. The reflection is that majority of the respondents are well educated people who made meaningful impact on this questionnaire. Most of the respondents had occupation.

Table 2 also evidently revealed that 88 respondents which represent $90.7 \%$ sampled population were into various entrepreneurships while the remaining 9.3\% were civil servants. The main occupation of the respondents could have seriously also affected regularity of their income. Those respondents that have regular big income source from businesses may have high susceptibility to hotel services when compared to a civil servant with irregular salary or farmers with seasonal variation in production The implication of the study findings is that the main occupation engaged in by the respondents predisposes them to hotel getting services from hotels in Abeokuta Metropolis.

This implied that the business class respondents mostly patronize and valued quality service delivery in hotels. It was also important that there were substantial number of respondents that have long years of hotel patronage. This represents $54.6 \%$ of the respondents that filled and returned the questionnaires.

However, all the respondents have hotel patronage experience. This made their contributions wellarticulated. The table also showed the frequency distribution that respondents are mostly Muslims and Christians which filled and returned the questionnaires. The distribution further indicates that Muslims have the larger percentage (59.8\%), while Christians have $40.2 \%$.

This further confirms that both Muslims and Christians enjoy hotel services and are the major patrons of hotels in Abeokuta metropolis. 
Table 1.Socio-Economic characteristics of Respondents

\begin{tabular}{llll}
\hline Particulars & Frequency & Percentage & Cumulative \\
\hline Gender: & 79 & $81.4 \%$ & 81.4 \\
Male & 18 & $18.6 \%$ & $\mathbf{1 0 0 . 0}$ \\
Female & & & \\
Age : & 18 & $18.6 \%$ & 18.6 \\
20-30yrs & 46 & $47.4 \%$ & 66.0 \\
30-40yrs & 29 & $29.9 \%$ & 95.9 \\
40-50yrs & 4 & $4.1 \%$ & $\mathbf{1 0 0 . 0}$ \\
50 above & & & \\
Marital Status: & 77 & $79.4 \%$ & 79.4 \\
Married & 9 & $9.3 \%$ & 88.7 \\
Single & 3 & $3.1 \%$ & 91.8 \\
Separated/Divorced & 8 & $8.2 \%$ & $\mathbf{1 0 0 . 0}$ \\
Widowed & & & \\
Educational: & 11 & $11.3 \%$ & 11.3 \\
M.sc, MBA, MA/Phd. & 73 & $75.3 \%$ & 86.6 \\
Bsc./HND & 10 & $10.3 \%$ & 96.9 \\
NCE/OND & 3 & $3.1 \%$ & $\mathbf{1 0 0 . 0}$ \\
WASC/GCE & & & \\
Occupation: & 9 & $9.3 \%$ & 9.3 \\
Civil servant & 88 & $90.7 \%$ & $\mathbf{1 0 0 . 0}$ \\
Entrepreneur & & & \\
Hotel Patronage Exp: & & $7.2 \%$ & 7.2 \\
1-5yrs & 7 & $38.1 \%$ & 45.4 \\
6-10yrs & 37 & $54.6 \%$ & $\mathbf{1 0 0 . 0}$ \\
11yrs above. & 53 & & \\
Religion: & & $59.8 \%$ & 59.8 \\
Christian & 58 & $40.2 \%$ & $\mathbf{1 0 0 . 0}$ \\
Muslim & 39 & Source: Field survey, 2018. & \\
\hline & & & \\
& & &
\end{tabular}

Identification of dimensions of service quality: The cases of whether tangible was one of the dimensions of service quality in practice in the hotels was assessed in the study, and 66 respondents which represent $68 \%$ agreed that facilities, equipment, physical appearance of both staff and buildings were actually on ground in the hotel while 31 respondents which represent $32 \%$ disagreed as shown in Table 2. It is pertinent to know that hotel users are usually eager to know and assess the facilities and other various equipment available for operations in the hotel for their personal satisfaction. In the course of doing that, some of them would decide whether to stay or not to stay in such hotel. However, the analysis of respondents' questionnaires showed that some of the hotels which represent about $85 \%$ actually have facilities, equipment, with welldressed staff. Reliability as a dimension of service quality in practice in the hotels as indicated in the Table 2 revealed $70.1 \%$ disagreed that performing service dependably and accurately reflected in the hotel staff behaviour, while $29.9 \%$ agreed. The implication of this is that there is a great challenge in the area of staff's ability to perform service dependably and accurately in the hotels. Also, with regard to responsiveness as a dimension of service quality is in practice in the hotels, $63(65 \%)$ of respondents disagreed that willingness to help and respond to customer needs reflected in the hotel staff attitudes. The remaining $35 \%$ of respondents agreed. This implied that majority of hotels in Abeokuta Metropolis have staff attitudinal problems in the area of willingness to assist and respond to customer needs. Assurance as one of the dimensions also of service qualities is put in place in the hotels, $59.9 \%$ who returned their questionnaires disagreed that the ability of employees to inspire confidence and trust is actually in practice in the hotel. This also has to do with staff attitudinal skill challenge in the area of their ability to inspire confidence and trust in their customers. This is well pronounced in hotels in Abeokuta Metropolis. The response about empathy is also one of service qualities in practice in the hotels, as $66 \%$ of respondents disagreed that the staff of the hotel are involved in given individualized caring service. This obviously result that majority of the staff are not showing empathy to their customers. The table below clearly shows the various responses to 5 Likert Scale questions by the respondents, the sample Mean X, and the Standard deviation $(\delta)$ scored.

Examining the relationships between Service Quality and Customer satisfaction: Customers' derived satisfaction from the facilities and equipment available in the hotel, revealed $34 \%$ of respondents rated satisfactory comments as against $66 \%$ unsatisfactory comments with the satisfaction derived from the facilities and equipment available in the hotel shown in Table 3 below. This means that the hotel is having challenge with facilities and equipment for their various operations. The responses on customers getting satisfaction from the foods and beverages provided in the restaurant, $53.7 \%$ of respondents rated the food and beverages served as unsatisfactory, while the other $46.3 \%$ rated satisfactory. The implication of this is that there was a little challenge in the area of food and beverages preparation, production and service. The item on customers deriving satisfaction from the hotel rooms, physical structure of the hotel and employees' appearance revealed that $55.6 \%$ of respondents rated hotel rooms, physical structure and employees' appearance as unsatisfactory, while other (44.4\%) rated satisfactory. The implication of this was that there was a little challenge in the area of lodging, physical structure and employees' mode of dressing which requires urgent attention. 
Table 2.Identifying various dimensions of service qualities in selected hotels in Abeokuta Metropolis.

\begin{tabular}{|c|c|c|c|c|c|c|c|c|}
\hline $\begin{array}{l}\mathbf{S} / \\
\mathbf{N}\end{array}$ & Questions & $\begin{array}{l}\text { Strongly } \\
\text { Agreed }\end{array}$ & Agreed & Undecided & Disagreed & $\begin{array}{l}\text { Strongly } \\
\text { Disagreed }\end{array}$ & Mean & $\begin{array}{l}\text { Standard } \\
\text { Deviation }\end{array}$ \\
\hline 1 & $\begin{array}{l}\text { Do you think 'Tangibles' } \\
\text { which refers to the facilities, } \\
\text { equipment, and employees' } \\
\text { appearance actually present } \\
\text { in the hotel? }\end{array}$ & $\begin{array}{l}27 \\
(27.8 \%)\end{array}$ & $\begin{array}{l}39 \\
(40.2 \%)\end{array}$ & - & $\begin{array}{l}24 \\
\quad(24.7 \%)\end{array}$ & ${ }^{7}(7.2 \%)$ & 3.57 & 1.322 \\
\hline 2 & $\begin{array}{l}\text { Do you think 'Reliability' } \\
\text { whichrefers to performing } \\
\text { service dependably and } \\
\text { accurately actually reflected } \\
\text { in the hotel staff behaviour? } \\
\text { Do you think }\end{array}$ & $\begin{array}{l}13 \\
(13.4 \%)\end{array}$ & $\begin{array}{l}16 \\
(16.5 \%)\end{array}$ & - & $\begin{array}{l}47 \\
\quad(48.5 \%)\end{array}$ & $\begin{array}{l}21 \\
(21.6 \%)\end{array}$ & 2.52 & 1.355 \\
\hline 3 & $\begin{array}{l}\text { 'Responsiveness' which } \\
\text { refers to willingness to help } \\
\text { and respond to customer } \\
\text { needs really reflected in the } \\
\text { hotel staff attitudes? }\end{array}$ & $\begin{array}{c}15 \\
(15.5 \%)\end{array}$ & $\begin{array}{l}19 \\
(19.6 \%)\end{array}$ & - & $\begin{array}{c}44 \\
(45.4 \%)\end{array}$ & $\begin{array}{l}19 \\
(19.6 \%)\end{array}$ & 2.66 & 1.399 \\
\hline 4 & $\begin{array}{l}\text { Do you think 'Assurance' } \\
\text { which refers to the ability of } \\
\text { employees to inspire } \\
\text { confidence and trust actually } \\
\text { in practice in the hotel? }\end{array}$ & $\begin{array}{l}18 \\
(18.6 \%)\end{array}$ & $\begin{array}{l}21 \\
(21.6 \%)\end{array}$ & - & $\begin{array}{l}42 \\
(43.3 \%)\end{array}$ & $\begin{array}{l}16 \\
(16.5 \%)\end{array}$ & 2.82 & 1.429 \\
\hline 5 & $\begin{array}{l}\text { Do you think 'Empathy' } \\
\text { which refers to the extent at } \\
\text { which caring individualized } \\
\text { service is given by staff is in } \\
\text { practice in the hotel? }\end{array}$ & $\begin{array}{l}16 \\
(16.5 \%)\end{array}$ & $\begin{array}{l}17 \\
(17.5 \%)\end{array}$ & - & $\begin{array}{l}56 \\
(57.7 \%)\end{array}$ & $\begin{array}{l}8 \\
(8.2 \%)\end{array}$ & 2.76 & 1.305 \\
\hline
\end{tabular}

Source: Field survey, 2018.

Table 3: Examining the relationship between the Service Quality experienced and Customer Satisfaction

\begin{tabular}{|c|c|c|c|c|c|c|c|c|}
\hline $\mathrm{S} / \mathrm{N}$ & Questions & Excellent & $\begin{array}{l}\text { Very } \\
\text { Good }\end{array}$ & Good & Fair & Poor & Mean & $\begin{array}{l}\text { Stand. } \\
\text { Deviation }\end{array}$ \\
\hline 1 & $\begin{array}{l}\text { What satisfaction do you derive } \\
\text { from the facilities and equipment } \\
\text { available in the hotel? }\end{array}$ & $\begin{array}{l}16 \\
(16.5 \%)\end{array}$ & $\begin{array}{l}17 \\
(17.5 \%)\end{array}$ & $\begin{array}{l}8 \\
(8.2 \%)\end{array}$ & $\begin{array}{l}32 \\
(33.0 \%)\end{array}$ & $\begin{array}{l}24 \\
(24.7 \%)\end{array}$ & 2.68 & 1.440 \\
\hline 2 & $\begin{array}{l}\text { What satisfaction do you get from } \\
\text { the foods and beverages provided } \\
\text { for you in the restaurant? }\end{array}$ & $\begin{array}{c}8 \\
(8.2 \%)\end{array}$ & $\begin{array}{c}14 \\
(14.4 \%)\end{array}$ & $\begin{array}{c}23 \\
(23.7 \%)\end{array}$ & $\begin{array}{c}37 \\
(38.1 \%)\end{array}$ & $\begin{array}{c}15 \\
(15.5 \%)\end{array}$ & 2.62 & 1.159 \\
\hline 3 & $\begin{array}{l}\text { What satisfaction do you derive } \\
\text { from the hotel rooms, physical } \\
\text { structure of the hotel and } \\
\text { employees' appearance? }\end{array}$ & $\begin{array}{c}11 \\
(11.3 \%)\end{array}$ & $\begin{array}{l}13 \\
(13.4 \%)\end{array}$ & $\begin{array}{l}19 \\
(19.6 \%)\end{array}$ & $\begin{array}{l}33 \\
(34.0 \%)\end{array}$ & $\begin{array}{l}21 \\
(21.6 \%)\end{array}$ & 2.59 & 1.281 \\
\hline 4 & $\begin{array}{l}\text { What satisfaction do you get } \\
\text { from the staff' ability to perform } \\
\text { the promised service accurately } \\
\text { and dependably? }\end{array}$ & $\begin{array}{c}7 \\
(7.2 \%)\end{array}$ & $\begin{array}{c}11 \\
(11.3 \%)\end{array}$ & $\begin{array}{l}22 \\
(22.7 \%)\end{array}$ & $\begin{array}{l}39 \\
(40.2 \%)\end{array}$ & $\begin{array}{l}18 \\
(18.6 \%)\end{array}$ & 2.48 & 1.138 \\
\hline 5 & $\begin{array}{l}\text { What satisfaction do you derive } \\
\text { from the staff willingness to help } \\
\text { you and other customers to } \\
\text { provide meals, beverages, and } \\
\text { other auxiliary services? }\end{array}$ & $\begin{array}{l}14 \\
(14.4 \%)\end{array}$ & $\begin{array}{l}25 \\
(25.8 \%)\end{array}$ & $\begin{array}{l}31 \\
(32.0 \%)\end{array}$ & $\begin{array}{l}15 \\
(15.5 \%)\end{array}$ & $\begin{array}{l}12 \\
(12.4 \%)\end{array}$ & 3.14 & 1.216 \\
\hline 6 & $\begin{array}{l}\text { What satisfaction do you derive } \\
\text { from the employees' displaying } \\
\text { good behaviour, knowledge and } \\
\text { courtesy to convey trust and } \\
\text { confidence? }\end{array}$ & $\begin{array}{c}5 \\
(5.2 \%)\end{array}$ & $\begin{array}{l}18 \\
(18.6 \%)\end{array}$ & $\begin{array}{l}21 \\
(21.6 \%)\end{array}$ & $\begin{array}{l}38 \\
(39.2 \%)\end{array}$ & $\begin{array}{l}15 \\
(15.5 \%)\end{array}$ & 2.59 & 1.116 \\
\hline 7 & $\begin{array}{l}\text { What satisfaction do you derive } \\
\text { from the employees displaying } \\
\text { caring and individualized } \\
\text { attention to you? }\end{array}$ & $8(8.2 \%)$ & $\begin{array}{c}18 \\
(18.6 \%)\end{array}$ & $\begin{array}{c}17 \\
(17.5 \%)\end{array}$ & $\begin{array}{c}41 \\
(42.3 \%)\end{array}$ & $\begin{array}{c}13 \\
(13.4 \%)\end{array}$ & 2.66 & 1.172 \\
\hline
\end{tabular}

The implication that customer get satisfaction from the staff' ability to perform the promised service accurately and dependably revealed that $58.8 \%$ of respondents rated staff ability to discharge service 
accurately and dependably unsatisfactory, while $41.2 \%$ rated it satisfactory. The implication of this was that the hotel was having little challenges as regard staff ability to discharge service accurately and reasonably. On the item of customers deriving satisfaction from the staff willingness to help them to provide meals, beverages, and other auxiliary services showed that $72.1 \%$ of respondents rated staff willingness to help provide meals, beverages, and other services to customers satisfactory. This was good enough when compared to $27.9 \%$ who rated them poor. The employees' displaying good behaviour, knowledge and courtesy to convey trust and confidence as indicated on the Table 3 revealed $54.6 \%$ of respondents appraising staff displaying good behaviour, knowledge and courtesy to convey trust and confidence unsatisfactorily. This shows that the hotel was having major challenge in this area. The issue of whether customers get satisfaction from the employees displaying caring and individualized attention revealed that $55.7 \%$ of respondents also appraised staff displaying caring and individualized attention to customers as unsatisfactory, while others were fairly satisfactory. This implied that the hotel was having challenge in this area since the feelings of customers patronizing the hotels are unpleasant. The table below clearly explains the various responses to 5 Likert Scale questions by the respondents, the sample Mean $(\mathrm{X})$, and the Standard deviation $(\delta)$ score.

Table 4: Solutions to the deficient service quality in the hotels

\begin{tabular}{|c|c|c|c|c|c|c|c|c|}
\hline & Questions & Strongly Agree & Agree & Undecided & Disagreed & $\begin{array}{l}\text { Strongly } \\
\text { Disagreed }\end{array}$ & Mean & $\begin{array}{l}\text { Standard } \\
\text { Deviation }\end{array}$ \\
\hline 1 & $\begin{array}{l}\text { Do you think the procurement } \\
\text { of standard equipment; enough } \\
\text { quality facilities will give } \\
\text { Customer the necessary } \\
\text { satisfaction? }\end{array}$ & 22 (22.7\%) & $\begin{array}{l}49 \\
(50.5 \%)\end{array}$ & - & $\begin{array}{l}15 \\
(15.5 \%)\end{array}$ & $\begin{array}{l}11 \\
(11.3 \%)\end{array}$ & 3.58 & 1.306 \\
\hline 2 & $\begin{array}{l}\text { Do you think the training of } \\
\text { staff on physical appearance } \\
\text { will give customer the } \\
\text { deserving satisfaction? }\end{array}$ & $\begin{array}{l}24 \\
(24.7 \%)\end{array}$ & $\begin{array}{l}45 \\
(46.4 \%)\end{array}$ & - & $\begin{array}{l}19 \\
(19.6 \%)\end{array}$ & 9 & 3.58 & 1.306 \\
\hline 3 & $\begin{array}{l}\text { Do you think the training of } \\
\text { staff on best behavioral } \\
\text { practices to convey trust and } \\
\text { confidence to customers will } \\
\text { give customers the necessary } \\
\text { satisfaction? }\end{array}$ & $18 \quad(18.6 \%)$ & $\begin{array}{l}48 \\
49.5 \%)\end{array}$ & - & $\begin{array}{l}17 \\
(17.5 \%)\end{array}$ & $\begin{array}{l}14 \\
(14.4 \%)\end{array}$ & 3.40 & 1.359 \\
\hline 4 & $\begin{array}{l}\text { Do you think more efforts on } \\
\text { efficiency of reservation and } \\
\text { courtesy of receptionist will } \\
\text { give customers the satisfaction } \\
\text { they deserve? }\end{array}$ & $23 \quad(23.7 \%)$ & $\begin{array}{l}44 \\
(45.4 \%)\end{array}$ & - & $\begin{array}{l}12 \\
(12.4 \%)\end{array}$ & $\begin{array}{l}18 \\
(18.6 \%)\end{array}$ & 3.43 & 1.450 \\
\hline 5 & $\begin{array}{l}\text { Do you think more efforts on } \\
\text { cleanliness; quality, comfort } \\
\text { and décor, and room } \\
\text { maintenance will give } \\
\text { customer the satisfaction they } \\
\text { deserve? }\end{array}$ & $27 \quad(27.8 \%)$ & $\begin{array}{l}46 \\
(47.4 \%)\end{array}$ & - & 9 & $\begin{array}{l}15 \\
(15.5 \%)\end{array}$ & 3.63 & 1.387 \\
\hline 6 & $\begin{array}{l}\text { Do you think more efforts on } \\
\text { quality food and beverages will } \\
\text { give customer satisfaction they } \\
\text { deserve? }\end{array}$ & $19 \quad(19.6 \%)$ & $\begin{array}{l}51 \\
(52.6 \%)\end{array}$ & - & $\begin{array}{l}11 \\
(11.3 \%)\end{array}$ & $\begin{array}{l}16 \\
(16.5 \%)\end{array}$ & 3.47 & 1.370 \\
\hline
\end{tabular}

Solutions to deficient service quality in the hotels: Procurement of standard equipment, enough quality facilities will give customer the necessary satisfaction revealed that $73.2 \%$ of respondents agreed that the procurement of standard equipment, enough quality facilities will give customer the necessary satisfaction, implying that if all these items are available and utilized as applicable, customers will get value for their money. Training of staff on physical appearance will give customer the deserving satisfaction, and thus $71.1 \%$ of respondents agreed that training of staff on physical appearance will give customer the deserving satisfaction. It is belief that appearance plays a significant role in quality service delivery to customers. This was because the way one looks usually determines the feelings of customers about the product/service being rendered. If staff appears grotesque, the customer may decide not to accept the food or drinks being offered. Also again, behavioural practices to convey trust and confidence to customers will give customers the necessary satisfaction and $68.1 \%$ of respondents agreed that training of staff on best behavioural practices to convey trust and confidence to customers gave customers the necessary satisfaction, and impressive repeat business. 
Table 5: Relationship between respondents' socio-economic characteristics and satisfaction.

\begin{tabular}{llllll}
\hline S/N & VARIABLES & Df & $\begin{array}{l}\mathrm{X}^{2} \\
{ }^{c a l}(0.05)\end{array}$ & $\begin{array}{l}\text { Significance } \\
(\mathrm{p} \leq 0.05)\end{array}$ & Decision \\
\hline $\mathbf{1}$ & Age & 3 & $38.959^{\mathrm{a}}$ & 0.000 & Significant \\
$\mathbf{2}$ & Marital Status & 3 & $153.845^{\mathrm{a}}$ & 0.000 & Significant \\
$\mathbf{3}$ & Educational level & 3 & $132.237^{\mathrm{a}}$ & 0.000 & Significant \\
$\mathbf{4}$ & Occupation & 1 & $64.340^{\mathrm{b}}$ & 0.000 & Significant \\
$\mathbf{5}$ & Hotel patronage exp. & 2 & $33.732^{\mathrm{c}}$ & 0.000 & Significant \\
$\mathbf{6}$ & Religion & 1 & $3.722^{\mathrm{b}}$ & 0.054 & Not significant \\
\hline & & Source: Field survey, 2018 &
\end{tabular}

Table 6: Relationship between service qualities and Customer satisfaction.

\begin{tabular}{|c|c|c|c|c|c|}
\hline $\mathbf{S} / \mathbf{N}$ & Variables & Df & $\mathrm{X}^{2 \text { cal. }}(0.05)$ & Significance $(p \leq 0.05)$ & Decision \\
\hline 1 & $\begin{array}{l}\text { What satisfaction do you } \\
\text { derive from the facilities } \\
\text { and equipment available } \\
\text { in the hotel? }\end{array}$ & 4 & $16.866^{\mathrm{a}}$ & 0.002 & Significant \\
\hline 2 & $\begin{array}{l}\text { What satisfaction do you } \\
\text { get from the foods and } \\
\text { beverages provided for } \\
\text { you in the restaurant? }\end{array}$ & 4 & $25.835^{\mathrm{a}}$ & 0.000 & Significant \\
\hline 3. & $\begin{array}{l}\text { What satisfaction do you } \\
\text { derive from the hotel } \\
\text { rooms, physical structure } \\
\text { of the hotel, employees' } \\
\text { appearance? }\end{array}$ & 4 & $15.423^{\mathrm{a}}$ & 0.004 & Significant \\
\hline 4. & $\begin{array}{l}\text { What satisfaction do you } \\
\text { get from the staff 's } \\
\text { ability to perform the } \\
\text { promised service } \\
\text { accurately and } \\
\text { dependably? }\end{array}$ & 4 & $31.814^{\mathrm{a}}$ & 0.000 & Significant \\
\hline 5. & $\begin{array}{l}\text { What satisfaction do you } \\
\text { derive from the staff } \\
\text { willingness to help you } \\
\text { and other customers to } \\
\text { provide meals, } \\
\text { beverages, and other } \\
\text { auxillary services? }\end{array}$ & 4 & $13.876^{\mathrm{a}}$ & 0.008 & Significant \\
\hline 6. & $\begin{array}{l}\text { What satisfaction do you } \\
\text { derive from the staff } \\
\text { displaying good } \\
\text { behaviour, knowledge, } \\
\text { and courtesy to convey } \\
\text { trust and confidence? }\end{array}$ & 4 & $29.753^{\mathrm{a}}$ & 0.000 & Significant \\
\hline 7. & $\begin{array}{l}\text { What satisfaction do you } \\
\text { get from employees' } \\
\text { displaying caring and } \\
\text { individualized attention } \\
\text { to you? }\end{array}$ & 4 & $33.258^{\mathrm{a}}$ & 0.000 & Significant \\
\hline
\end{tabular}

This implies that, if customers are well trained in this area, the resultant effects on service will be well accepted. The query on if more efforts on efficiency of reservation and courtesy of receptionist will give customers the satisfaction they deserve revealed that $69.1 \%$ of respondents agreed that more efforts on efficiency of reservation and courtesy of receptionist will give customers the satisfaction they deserve, while $30 \%$ disagreed. The implication of this was that when customer is well received by receptionist of the hotel through provision of efficient reservation with courtesy and pleasantness, it will give customers the deserved satisfaction. The analysis indicates that few hotels are good in this area. As regard to if more efforts are given on cleanliness, quality, comfort and décor, and room maintenance would give customer the satisfaction they deserve only $75.2 \%$ of respondents agreed that more efforts would give customer the satisfaction they deserve. This implied that customers cherish cleanliness, comfort and good décor in their rooms and other areas of the hotel as a measure of satisfaction. Thus, more efforts in this area will make a difference. The question on whether more efforts on quality food and beverages will give customer the satisfaction they deserve revealed that $72.2 \%$ of respondents agreed that more efforts on quality food and beverages will give customer the satisfaction they deserve, while $27.8 \%$ disagreed. The implication of 
this was that majority of respondents appreciate quality foods and beverages at all times. Thus, providing them with this will go a long way in assuaging their dissatisfaction.

Relationship between respondents' socio-economic characteristics and satisfaction: Table 5 shows the relationship between socio-economic characteristics and satisfaction of the respondent. The results of the hypothesis test of relationship between selected socioeconomic characteristics of the respondents and their level of satisfaction with the service qualities in the hotel revealed that there was significant relationship ( $p$ $<0.05$ ) between age, education, marital status, religion and occupation and their level of satisfaction using chi-square test.

This implied that age, sex, education, household size, main occupation except religion of the respondents are associated with their level of satisfaction with the hotel service qualities in the study area. The chi square value of 789.537 with a degree of freedom (df) 325, the chi-square value of 0.000 ; is less than the tabulated chi- square value of 0.05 hence the null hypothesis $\left(\mathrm{H}_{\mathrm{o}}\right)$ is therefore rejected because there is no significant relationship between various service qualities and customer satisfaction while the alternative hypothesis $\left(\mathrm{H}_{1}\right)$ is accepted because there is a significant relationship between various service qualities and customer satisfaction

Table 6 shows the relationship between service qualities and customer satisfaction using chi square test. The chi square value of 839.999 with a degree of freedom (df) 325, the chi-square value of 0.000 ; is less than the tabulated chi- square value of 0.05 hence the null hypothesis (Ho) is therefore rejected because there is no significant relationship between various service qualities and customer satisfaction while the alternative hypothesis $\left(\mathrm{H}_{1}\right)$ is accepted because there is a significant relationship between various service qualities and customer satisfaction.

Conclusion: The study has revealed that service quality delivery by hotels to their various customers is very important to customer satisfaction as every hotel customer wants value for their money. Hotels would continue to enjoy impressive patronage of customers if the efficient service quality delivery that would make them feel happy and satisfied at all times was delivered. Therefore, it was pertinent to put every necessary machinery in place that would ensure that hotels are seen to constantly offer acceptable quality service to their numerous customers.

\section{REFERENCES}

Akinyele, S. (2010). Customer Satisfaction And Service Quality: Customer's Re-Patronage Perspectives. Global J. Manage. Bus. Res.110118.

Andrew, S. (2006); "Introduction to Tourism and Hospitality Industry"; TatMcGraw-Hill

Publishing.

Armstrong, RW; Mok, C (1997). The importance of cross-cultural expectations in the measurement of service quality perceptions in the hotel industry. Inter. J. Hospital. Manage. 16(2): 181-190.

Baker (2000); Principle of Hotel front office operation" $-2^{\text {nd }}$ Ed. London. Continuum pp.2, 6

Bernard, H. (1982). "Marketing services by managing the environment". Cornel hotel and Restaurant administration Quarterly 23, No1. May 1982. Pg 35-39.

Bitner, M. J.; Hubbert, A. R. (1994). Encounter satisfaction versus overall satisfaction versus quality: the customer's voice. Service quality: New directions in theory and practice. London: Sage.

Bolton, RN; Drew JH. (1991). A Multistage Model of Customers' Assessments of Service Quality and Value, J. Cons. Res. 17. 4: 375-384.

Brink, A.; Berndt, A. (2005). Customer Relationship Management and Customer Service". Lansdowne: Juta and Co. Ltd.

Bromley, DB. (2002).Comparing corporate reputations: League tables, quotients, benchmarks, or case studies. Corporate Reputation Review 5, 35-50.

Butt, MM; de Run, EC. (2010). Private healthcare quality: applying a SERVQUAL model, International J. Health Care Quality Assurance. 23 7. 658-673.

Chan, B.; Mackenzie, M. (2013). Tourism and hospitality studies: Introduction to hospitality.

Çiftçi, AG. (2006). Hizmet Kalitesive Bankacılık Sektöründe Hizmet Kalitesi Ölçümüne Yönelik BirUygulama. Yayın lanmamış Yüksek Lisans Tezi, D.E.Ü. Sosya 1Bilimler EnstitüsüI şletme Anabilim Dalı, İzmir. 
Coffman, (1980). Franching as a business expansion strategy in bed and breakfast industry.http://journals.sagepub.com>pgf.

Retrieved on $5^{\text {th }}$ May, 2018.

Cronholm, S.; Salomonson, N. (2014). Measures that matters: service quality in IT service management, International Journal of Quality and Service Sciences, Vol. 6 Iss: 1, pp.60-76.

Cronin, JJ; Taylor, SA, (1992).“Measuring Service Quality A re-examination an Extension, $J$. Market. 56, 3. 55-68

Dahiyat, SE; Akroush, MN; Abu-Lail, BN. (2011). "An integrated model of perceived service quality and customer loyalty: an empirical examination of the mediation effects of customer satisfaction and customer trust, Inter. J. Serv. Operations Manage. 9 (4). 453-490.

Dedeoğlu, BB; Demirer, H. (2015). Differences in service quality perceptions of stakeholders in the hotel industry, International Journal of Contemporary Hospitality Management". 27 (1). $130-14$.

Delbert, CM (1977). "Hand Book of Research Design and Social Measurement": (3rd Edition), New York; Longman

Denga, OI; Ali, A. (1983).An Introduction to Research Methods and Statistics in Education and Social Sciences". Savannah Publishers Ltd.

Ezejelue, AC; Ogwo, EO. (1990). "Basic Principles in Managing Research Project”. Onitsha, AfricanaRep Publishers Ltd.

Ford, R., Sturman, M; Heaton, C. (2011). Managing Quality Service in Hospitality: How Organizations Achieve Excellence in Guest Experience. 1st ed. Cengage Learning. New York.

Gronroos, C. (1990)."Relationship approach to marketing in service contexts: The marketing and organizational behaviour interface", Journal of Business Research, 20(1), 3-11.

Ikeagwu, EK (1998). Ground Work of Research methods and Procedures; Institute for Development Studies, University of Nigeria, Enugu Campus.
Jacques, LB (2005). 'Hotels: A brief History'. (www.hospitalitynet.org. Retrieved $5^{\text {th }}$ May, 2018.

Juran, J.; Godfrey, A. (1998). Juran's Quality Handbook. $5^{\text {th }}$ edition. McGraw-Hill. New York.

Karahan, Kasım. (2006). Hizmet Pazarlaması.(2. Bask1). İstanbul: Beta Basım Yayım.

Kinnear, TC; Taylor, JR (1983), Marketing Research (2nd Edition), McGraw Hill Co.

Kotler, P. (1996). Marketing management: analysis, planning, implementation and control. Englewood Cliffs New Jersey: Prentice-Hall Inc.

Little AP (2010). Wowing Customer Service Strategies, Key Success Factors to design and implement service excellence.www.adl.com .

Little, AB; Little, DW. (2009)."The home team approach to service quality: linking and leveraging communication between human resources, operations and marketing", Journal of Organizational Culture, Communication and Conflict, 13(2), 57-70.

Ladhari, R. (2009). A review of twenty years of SERVQUAL research, International Journal of Quality and Service Sciences, Vol. 1, Number 2.P.172-198.

Mohsin, Asad, ve Lockyer, Tim. (2010). Customer Perceptions of Service Quality in Luxury Hotelsin New Delhi, India: An Exploratory Study. International Journal of Contemporary Hospitality Management, 22(2), 160-173.

Moreira, AC.; Campos Duque Dias, .M. (2010).Tourism and Hospitality Management. Assessing the challenges of service quality in the terra quentetrans montana, Portugal, 16(1), 33.

Musaba, CN; Musaba, EC; Hoabeb, SIR (2014). Employee perceptions of service quality in the Namibian hotel industry: a Servqual approach. International Journal of Asian Social Science, 4(4), 535.

Oletewo, J. (2017). Analysing the moderating effect of customer loyalty on long run repurchase intentions. African Journal of Marketing Management, 9(3), 25-34. 
Opoku, RA., Yiadom, NA., Chong, CS.; Abratt, R. (2008). "The impact of internal marketing on the perception of se5rvice quality in retail banking: A Ghanaian case", Journal of financial Services Marketing, 13(4), 317-329.

Parasuraman, A., Zeithaml, VA. ; Berry LL. (1988). SERVQUAL: a multiple item scale for measuring consumer perceptions of service quality. Journal of Retailing, 64(5), 21-40.

Padma PC; Rajendran, EA. (2010). Service quality and its impact on customer satisfaction in Indian hospitals: Perspectives of patients and their attendants. Benchmarking: An International Journal; 17(17): 6.

Roper, S.; Fill, C. (2012).Corporate Reputation. Brand and Communication. Harlow: Pearson.

Rousan A, Ramzi M; Badaruddin Mohamed (2010).Customer Loyalty and its Impacts of Service Quality; The case of five star hotels in Jordan. International Journal of Human and social Sciences, 5; 13, 2010.

Sandberg, K. (2002). Kicking the tires of corporate reputation. Harvard Management Communication Letter, 5, 3-4.
Veal, A. J. (2011). Research methods for leisure and tourism: A practical guide. 4th ed. England: Pearson Education.

UNESCO, (2014).Hotel management http://unesdoc.unesco.org>images. Retrieved on $6^{\text {th }}$ May, 2018.

Wang, J. (2009). Issues and Challenges, and Trends facing Hospitality Industry.www.cscanada.net . Retrieved on $5^{\text {th }}$ April, 2018.

Yamane, T. (1964), Statistics: An Introductory Analysis; New York; Harper and Row.

Yılmaz,İ.(2007).OtelİşletmelerindeHizmetKalitesinin MüşterilerveYöneticilerAçısındanÖlçülmesi:İzm irÖrneği.YayınlanmamışDoktoraTezi,DokuzEyl ülÜniversitesiSosyalBilimlerEnstitüsüTurizmİşle tmeciliğiAnabilimDalı, İzmir. Zeithaml,

Berry, VA; Parasuraman, A. (1996). The behavioral consequences of service quality. J. Market.60, $31-46$.

Zekiri, J. (2011).Applying SERVQUAL Model and Factor Analysis in Assessing Customer Satisfaction with Service Quality: The Case of Mobile Telecommunications in Macedonia, 11(11): 86-101 